\title{
Photoacoustic Measurements of Black Carbon Light Absorption/Scattering Coefficients and Visibility Degradation in Jordan During 2007/2008
}

\author{
Khadeejeh M. Hamasha \\ Physics Departement, University of Tabuk, \\ Kingdom of Saudi Arabia
}

\section{Introduction}

Air is the name given to atmosphere used in breathing and photosynthesis. Air supplies us with oxygen which is essential for our bodies to live. Air consists of $79 \%$ nitrogen, $20 \%$ oxygen, $1 \%$ water vapor and inert gases. Air pollution is the introduction of chemicals, particulate matter, or biological materials that cause harm or discomfort to organisms into the atmosphere. Air pollutants are known as substances in the air that can cause harm to humans and the environment. These substances are not naturally found in the air at greater concentrations or in different locations from usual. Pollutants can be in the form of solid particles, liquid droplets, or gases. In addition, they may be arising from natural processes or human activities.

Pollutants can be classified as primary air pollutants or secondary air pollutants according to their sources. Usually, primary air pollutants are directly emitted from a process, such as ash from a volcanic eruption, sulfur dioxide released from factories or the carbon monoxide gas from a motor vehicle exhaust. Secondary pollutants are not emitted directly. But, they form in the air when primary pollutants interact or react. An example of a secondary pollutant is ground level ozone, which is one of the many secondary pollutants that make up photochemical smog. Some pollutants may be both primary and secondary: that is, they are both emitted directly and formed from other primary pollutants.

The primary air pollutants found in most urban areas are dispersed throughout the world's atmosphere in concentrations high enough to gradually serious health problems. This problems can occurs quickly when air pollutants are concentrated. The main sources of pollutants in urban areas are transportation and fuel composition in stationary sources, such as commercial, coal-burning power plant, cooling, and industrial heating.

One type of air pollution is the release of particles (aerosols) into the air from burning fuel for energy. Aerosols are defined as the relatively stable suspensions of solid or liquid particles in gas. There are many properties of particles that are important for their role in the atmospheric processes. These include number concentration, mass, size, chemical composition, and aerodynamic and chemical properties (Chang et al. 1982; Walker 1966). Of 
these, size is very important. It is related to the source of particles and their impact on health (Harber et al. 2003; Puntoni et al. 2004; Borm et al. 2005), visibility, and climate (FinlaysonPitts and Pitts 2000).

\section{Black carbon}

Light absorbing carbon particles (organic carbon and black carbon) are the most abundant and efficient light absorbing component in the atmosphere in the visible spectrum. It typically depends inversely on wavelength (Horvath 1993; Horvath 1997). Organic carbon is strongly wavelength dependent, with increased absorption for UV and short wavelength visible radiation, but hardly at all at $870 \mathrm{~nm}$. Black carbon is very likely to dominate at $870 \mathrm{~nm}$ (Lewis et al. 2008). When aerosols absorb light, the energy of the light is transferred to the particles as heat and eventually is given to the surrounding gas. Aerosol particles in the atmosphere have a great influence on fluxes of solar energy and the accompanied fluctuations in temperature caused by changes in the aerosol (Horvath 1993).

Black carbon, the main constituent of soot, is almost exclusively responsible for aerosol light absorption at long wavelength visible radiation and near infrared wavelengths. This type of pollution is sometimes referred to as black carbon pollution. Air pollution caused by black carbon particles has been a major problem since the beginning of the industrial revolution and the development of the internal combustion engine. Scientific publications dealing with the analysis of soot and smoke date back as early as 1896 (Arrhenius 1896). Mankind has become so dependent on the burning of fossil fuels (petroleum products, coal, and natural gas) that the sum total of all combustion-related emissions now constitutes a serious and widespread problem, not only to human health (Gillmour et al. 2004, Gardiner et al. 2001, Parent et al. 2000), but also to the entire global environment (IPCC 1996, Finlayson-Pitts and Pitts 2000).

Absorption of solar radiation by black carbon is expected to lead to heating of the atmosphere since the light energy is converted into thermal energy (Finlayson-Pitts and Pitts 2000). This is the opposite effect of scattering of light by particles into the upper atmosphere. This heating effect would be expected to be most important in polluted urban areas (Liu and Smith 1995, Horvath 1995). Black carbon aerosol light absorption reduces the amount of sunlight available at the surface to drive atmospheric circulation and boundary layer development.

Even the burning of wood and charcoal in fireplaces and barbeques can release significant quantities of soot into the air. Some of these pollutants can be created by indoor activities such as smoking and cooking. So pollution also needs to be considered inside homes, offices, and schools. According to the world health report 2002 indoor air pollution is responsible for $2.7 \%$ of the global burden of disease (WHO 2010). We spend about $80-90 \%$ of our time inside buildings, and so our exposure to harmful indoor pollutants can be serious (Harber et al. 2003; Puntoni et al. 2004; Borm et al. 2005). It is therefore important to consider both indoor and outdoor air pollution.

\section{Jordan}

Jordan is located between $29^{\circ} 10^{\prime} \mathrm{N}-33^{\circ} 45^{\prime} \mathrm{N}$ and $34^{\circ} 55^{\prime} \mathrm{E}-39^{\circ} 20^{\prime} \mathrm{E}$. The discovery of oil in the Arabian Peninsula has resulted in fast growth and social and economical development 
in the Gulf States and their neighboring countries including Jordan, which provides skilled workers. The social and economic development in Jordan has been accompanied by an increase in the consumption of oil for different needs, including residential, commercial, industrial, transportation, and power generation. According to figures published by the Department of Statistics, Jordan imported about six million tons of crude oil in 2005 (Department of Statistics, 2010).

Combustion of oil and other fossil fuel is recognized as a major source of air pollution in urban areas. Several airborne substances can remain in the atmosphere for weeks, and travel over hundreds of kilometers, making air pollution a global problem. Common pollutants that are generated through oil combustion are carbon oxides $\left(\mathrm{CO}\right.$ and $\left.\mathrm{CO}_{2}\right)$, sulfur oxides (SOx), nitrogen oxides (NOx), particulate matter (PM), and volatile organic compounds (VOCs). Tropospheric ozone is a secondary pollutant that is generated in the troposphere through a photosynthesis reaction of NOx and VOCs in the presence of solar radiation. It is becoming a major threat to air quality in metropolitan areas.

Emissions from motor vehicles account for 50-90 percent of air pollution in urban centers (Cooper et al. 1996; Gillies et al 2008). There are just over 750,000 vehicles licensed in Jordan, of which $77.5 \%$ are registered in the capital, Amman (Department of Driving and Vehicles Licensing 2010). More than $31 \%$ of the vehicles in Jordan are diesel-powered. Vans and trucks represent $33 \%$ and $42.7 \%$ of the total diesel-powered vehicles, respectively. Most public transportation vehicles work inside cities, especially Amman and Zarqa. Particles emanated from motor vehicles contain sulfate, carbonaceous particles, and a large number of chemicals (Kassel 2003).

Other sources of air pollution in Jordan include power generation, which uses heavy oil and natural gas; cement production, which uses oil shale; cooking; home furnaces fueled by diesel, natural gas, or kerosene; in addition wood stoves. The unexpected jump in oil prices experienced during winter of 2007 has forced people with low income in the countryside and mountainous areas to switch to wood stoves because they use either olive husk or wood, which are available at low, or no, cost in their immediate surroundings.

The negative health impact of air pollution has been widely studied in humans and animals. Findings of several epidemiology studies pointed out that high levels of air pollution may result in several health problems, including eye irritation, skin irritation, asthma, lung cancer, cardiovascular issues, high blood pressure, lung tumors, and increasing mortality rate (Pope et al. 1995; Künzli et al. 2000; Pope et al. 2002; Takano et al. 2002; Sanjay Rajagopalan 2008). Over 300,000 cases of chronic bronchitis, 500,000 asthma attacks, and 16 million lost person-days of activity recorded in Europe were blamed on vehicle emissions (Künzli et al. 2000). Exposure to high levels of $\mathrm{SO}_{2}$ causes impairment of the respiratory function and aggravates existing respiratory and cardiac illnesses (Andre 2001). Long-term exposure to $\mathrm{NO}_{2}$ lowers resistance to respiratory infections and aggravates existing chronic respiratory diseases. In addition to its adverse impact on humans, air pollution has adverse impacts on animals, and vegetation, in addition to loss of crops.

In spite of the fast growth of urban areas and industrial activities in Jordan, air pollution has not received due attention. Air quality is not routinely monitored anywhere except at Alhashameiah (to the northeast of Zarqa), which experiences high levels of sulfur oxides and particulates. There have been a few studies that tackled air pollution in Jordan, but they 
have been limited to three stations only: Downtown and Shmeisani areas in Amman, as well as Al-Hashemyeh. Those studies have pointed out that local air quality is poor where concentrations of criteria pollutants (NOx, SOx, CO, $\mathrm{PM}_{10}$, TSP, Lead, and hydrogen sulfide) exceed the National Air Quality Standards (Asi et al. 2001; Hamdi 2008). The Jordanian ministry of environment has recently launched a project to establish an air quality monitoring network throughout the country, but actual steps towards that goal have not been taken yet.

\section{Measurements of black carbon levels using photoacoustic technique}

Photoacoustic instrument (Arnott 1999) is used to measure the black carbon light absorption coefficients. Data were displayed as absorption coefficients in $1 / \mathrm{Mm}$, and were later converted to black carbon mass concentration. The photoacoustic instrument (figure 1) utilizes a microphone to record sound issuing from heat transferred from light absorbing aerosol to the surrounding air. A power meter records the laser power. The ratio of microphone pressure and laser power is used to obtain the light absorption coefficient. Photoacoustic instruments have a very large dynamic range of measurement, and are not influenced by artifacts due to filter loading and scattering aerosol associated with filterbased sampling methods (Arnott et al. 2005).

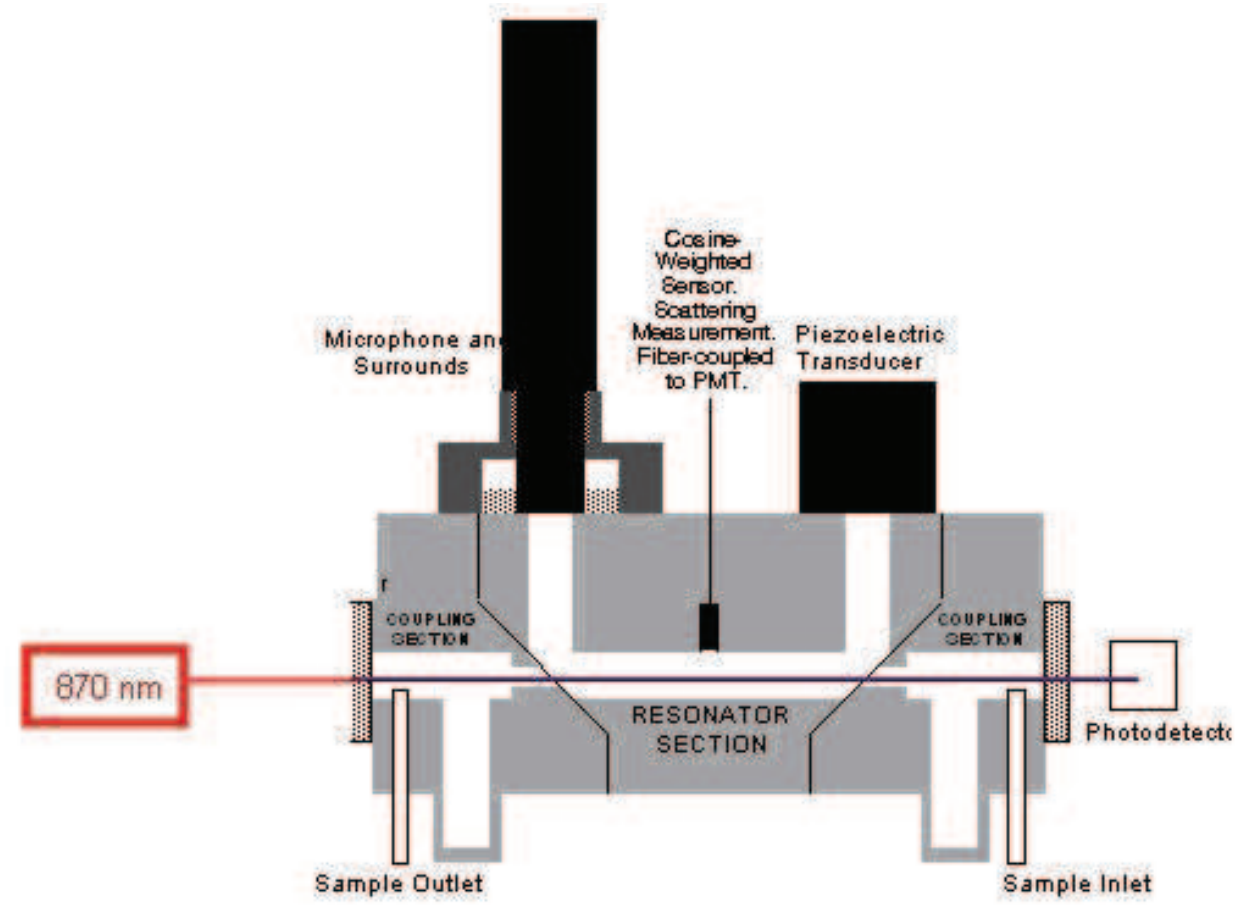

Fig. 1. A schematic view of the photoacoustic spectrometer instrument. (PMT is a photomultiplier) 
Black carbon and organic carbon are the most efficient light-absorbing aerosol species in the visible spectral range. Organic carbon is strongly wavelength dependent, with increased absorption for UV and short wavelength visible radiation, but hardly at all at $870 \mathrm{~nm}$. Black carbon is very likely to dominate at $870 \mathrm{~nm}$ (Rosen et al. 1978; Lindberg et al. 1993; Lewis et al. 2008). Thus the measurement of aerosol light absorption at wavelengths in the long visible wavelength is correlated to the measurement of black carbon. Light absorption by particles depends on the wavelength of the incident light. The relationship between the aerosol absorption coefficients, $B_{a b s}$ and the corresponding black carbon mass concentration (BC) is established by the aerosol specific mass absorption efficiency $\sigma_{a b s}$ via the relationship:

$$
B_{a b s}=B C \sigma_{a b s}
$$

The magnitude of $\sigma_{a b s}$ ranges from 2 to $20 \mathrm{~m}^{2} / \mathrm{g}$ (Liousse et al. 1993). Black carbon mass concentrations (BC) are calculated from $\mathrm{B}_{\mathrm{abs}}$ using the light absorption efficiency for black carbon, $\alpha_{\mathrm{a}}$, such that (Arnott et al. 1999):

$$
\begin{gathered}
\mathrm{B}_{\mathrm{abs}}\left(\mathrm{Mm}^{-1}\right)=\mathrm{BC}\left(\mu \mathrm{g} / \mathrm{m}^{3}\right) \times \alpha_{\mathrm{a}}\left(\mathrm{m}^{2} / \mathrm{gm}\right) \\
\text { and, } \\
\alpha_{\mathrm{a}}=10 \mathrm{~m}^{2} / \mathrm{gm} \text { for } \lambda=532 \mathrm{~nm}
\end{gathered}
$$

Since $\mathrm{B}_{\mathrm{abs}}$ is proportional to $1 / \lambda$ (Kirchstetter et al. 2004); then $\alpha_{\mathrm{a}}$ is also proportional to $1 / \lambda$. Therefore,

$$
\begin{aligned}
\alpha_{a}(870 n m)= & \alpha_{a}(532 n m)\left(\frac{870}{532}\right)^{-1} \\
& =6.11 \mathrm{~m}^{2} / \mathrm{g}
\end{aligned}
$$

Substituting back in equation (2) yields

$$
\mathrm{BC}(870 \mathrm{~nm})=\mathrm{B}_{\mathrm{abs}}(870 \mathrm{~nm}) / 6.11
$$

\section{Black carbon levels in Jordan}

Measurements of black carbon light absorption coefficients $\left(\mathrm{B}_{\mathrm{abs}}\right)$ using photoacoustic instrument at the wavelength of $870 \mathrm{~nm}$ in different locations of Jordan show that $\mathrm{B}_{\mathrm{abs}}$ is higher for the locations in the city centers than the locations in the industrial centers during summer 2007( Hamasha et al. 2010). Low black carbon concentrations in the vicinity of industrial zones are attributed to the efficiency of tall stacks in reducing ground level concentrations of emitted substances. However, tall stacks do not really make air cleaner; they only carry black carbon and other pollutants to distant locations as seen from the results at the location in Zarqa downtown. Measurements carried out at Zarqa downtown 
gave the highest levels of black carbon concentration during summer as well as winter (Hamasha et al. 2010); because of numerous air pollution sources concentrated in the city. Zarqa is a growing industrial city with a population of about half a million as 2008 estimate (Department of Statistics 2010). It hosts about 35\% of the heavy industry in Jordan including the only oil refinery, an oil-based power plant, steel factories, a pipe factory, a wastewater treatment plant, to mention a few. A total of 2400 industrial activities are registered in the Zarqa Industrial Chamber.

$\mathrm{B}_{\mathrm{abs}}$ in Zarqa city center is about $179 \mathrm{Mm}^{-1}$ during summer day, 2007 And about $81 \mathrm{Mm}^{1}$ during winter day, 2008. While in Amman city center the measured values of $\mathrm{B}_{\mathrm{abs}}$ were about $67 \mathrm{Mm}^{-1}$ during summer day, 2007 and about $23 \mathrm{Mm}^{-1}$ during winter day, 2008(Hamasha et al. 2010).

Measurements at Ibbeen city center on a winter day $(28 / 2 / 2008)$ show that the city had relatively high levels of black carbon (about $72 \mathrm{Mm}^{-1}$ ) for such a small city that is not crowded with automobiles especially during winter. The city of Ibbeen is very cold in winter, and people usually use wood heaters. These heaters have chimneys outside that release significant amounts of black carbon particles as well as other pollutant gases.

Measurements of black carbon light absorption coefficients in six sites in Irbid city were done during summer 2007. The average value of $B_{a b s}$ of all the sites was about $40 \mathrm{Mm}^{-1}$. While the largest value was about $61 \mathrm{Mm}^{-1}$ in the city center (Hamasha and arnott 2009).

\section{Indoor air pollution by black carbon}

Measurements of the black carbon light absorption coefficients ( $\left.B_{\text {abs}}\right)$ using the photoacoustic instrument, at wavelength of $870 \mathrm{~nm}$, were done inside different buildings at Yarmouk University/Jordan on summer 2007. The sources of black carbon inside buildings were the human activities and the incoming aerosol from outside that travel with air. Inside these buildings there were no kitchens, so no cooking source of black carbon. As the time of the measurements was summer, there was no source black carbon from heating systems. This measurements show that $B_{a b s}$ are low inside buildings with a max value of about $8 \mathrm{Mm}^{-1}$ and an average value of $6 \mathrm{Mm}^{-1}$ ( Hamasha 2008). The building that has the highest level of black carbon is the closest building to very crowded main street. Crowded main street means a lot of automobiles and a lot of aerosol particles that could easily travel by air to the nearest building through the opened doors and windows.

Other indoor measurements of black carbon levels were conducting during the period, 20-26 January 2008 inside living rooms of different houses. During the period of measurements the temperatures were between $0^{\circ} \mathrm{C}$ and $10^{\circ} \mathrm{C}$. Ventilation in these living rooms is few minutes during the day, while operation of heaters is about 15 hours. These measurements indicated that the daily indoor black carbon levels were high with average value of about $19 \mu \mathrm{g} / \mathrm{m}^{3}\left(116 \mathrm{Mm}^{-1}\right)$ and $\max$ value of about $32 \mu \mathrm{g} / \mathrm{m}^{3}\left(196 \mathrm{Mm}^{-1}\right)$ Hamasha 2010a). The levels of the BC inside houses in winter were higher than that in summer. The reasons for that are: in summer doors and windows are opened most of the times which leads to a good ventilation, but in winter they are mostly closed to keep the warm inside. This means if there are pollutants species inside it stay inside. In addition, heaters in winter are another big source of pollutant species like black carbon caused by the incomplete combustion. 


\section{Impacts of serosols on the visibility in Irbid city}

Diurnal aerosol visible light absorption and scattering coefficients at the wavelength of 870 nm were obtained using the Photoacoustic Instrument at two sites of Irbid city, urban site and suburban site. The diurnal absorption and scattering patterns showed a strong variability from day to day at both site. During most of the study days, the highest absorption peaks appeared in the early morning, while those of scattering appeared at later times. The earlier absorption peaks could be attributed to the elevated black carbon emissions during the heavy traffic hours whereas the later scattering peaks are attributed to secondary aerosol formed photochemically in the atmosphere. During the sampling period, the suburban site exhibited on the average a higher aerosol scattering and a lower aerosol absorption contribution to the total aerosol visible light extinction and a better visibility than the urban site. The average visibility attributed to aerosol at the urban site dominated by urban scale and regional scale was $44 \mathrm{~km}$, while that of the suburban site was $115 \mathrm{~km}$ ( Hamasha 2010b).

\section{References}

Andre, Nel, E., Diaz-Sanchez, David and Li, Ning, (2001). The role of particulate pollutants in pulmonary inflammation and asthma: evidence for the involvement of organic chemicals and oxidative stress. Current Opinion in Pulmonary Medicine. $7(1), 20-26$.

Arnott, W. P., H. Moosmüller, C. F. Rogers, T. Jin, and R. Bruch. (1999). "Photoacoustic spectrometer for measuring light absorption by aerosols: Instrument description." Atmospheric Environment 33: 2845-2852.

Arnott, W P, Hamasha, K, Moosmüller, H, Sheridan, P J and Ogren, J A, "Towards aerosol light absorption measurements with a 7-wavelength Aethalometer: Evaluation with a photoacoustic instrument and a 3 wavelength nephelometer." Aerosol Science \& Technology 39 (2005) 17-29.

Arrhenius, S., "On the Influence of Carbonic Acid in the Air upon the Temperature of the Ground," Philos. Mag., 41, 237-276 (1896).

Asi, R.; Anani, F.; Asswaeir, J. "Studying Air Quality in Alhashemeiah Area/Zarqa". A report prepared by the royal scientific association for the general institution for the protection of the environment, Amman, Jordan, 2001.

Borm,PJ., RP. Schins, and C. Alberecht. (2004)."Inhaled particles and lung cance, part B: Paradigms and Risk Assess. "Int J Cancer;110(1):3-14

Chang, S. G., R. Brodzinsky, L. A. Gundle, and T. Novakov. "Chemical and Catalytic Properties of elemental carbon", In Particulate Carbon: Atmospheric Life Cycle (G. T. Wolff, and R. L. Klimsch, Ends.), pp. 159- 181, Plenum, New York, 1982.

Cooper, C.D., and Alley, F.C., (1996). Air Pollution Control: A Design Approach. Sci. Total Environ. 146/147, 27-34. Boston, MA: PWS Publishers.

Department of Driving and Vehicles Licensing. Amman, Jordan, 2010.

Department of Statistics, Amman, Jordan. http://www.dos.gov.jo/dos_home_a/main/index.htm, retrieved Dec,8, 2010.

Finlayson-Pitts, B. J. and J. James N. Pitts (2000). Chemistry of the Upper and Lower Atmosphere, Academic press. 
Gardiner K., M. van Tongeren, and M. Harrington, "Respiratory Health Effects from Exposure to Carbon Black; Results of the Phase 2 and 3 Cross Sectional Studies in the European Carbon Black Manufacturing Industry," Occup. Environ Med. 2001;58(8)496-503.

Gillies, J.; Abu-Allabanb, M.; Gertler, A; Lowenthal, D: Jennison, B; Goodrich, A. (2008). Enhanced PM2.5 Source Apportionment Using Chemical Mass Balance Receptor Modeling and Scanning Electron Microscopy. JJEES, 1:(1) 1-9.

Gillmour, PS., A. Ziesenis, ER. Morrison, MA. Vickers, EM. Drost, I. Ford, E. Karg, C. Mossa, A. Schroeppel, GA. Ferron, J. Hayder, M. Greaves, W. MacNee, and K. Donaldson, "Pulmonary and Systematic Effects of Short-Term Inhilation Exposure to Ultrafine Carbon Black Particles," Toxicol Appl. Pharmacol. 2004 :195(1): 35-44

Hamasha, K. M., (2008), "Measurements of black carbon levels using photoacoustic technique inside different buildings at Yarmouk University/ Jordan", Jordan Journal of Physics, Vol. 1 No. 2, pp 1-8.

Hamasha, K. M. and W. P., Arnott, ( 2009), "Photoacoustic measurements of carbon light absorption coefficients in Irbid city, Jordan, Environ. Monit. Assess, Doi 10.1007/s10661-009-1017-3

Hamasha, K. M., M. S. Almomani, M. Abu-Allaban and W.P.Arnott (2010) "Study of black carbon levels in city centers and industrial centers in Jordan", Jordan Jornal of Physics,volume3,No1, pp1-8.

Hamasha, K. M., (2010a), "Black carbon indoor air pollution from space heating in winter", Abhath al-Yarmouk Basic Sciences and Engineering, Vol. 19 No. 2, pp $47-53$.

Hamasha, K. M., (2010b), “Visibility Degradation and light Scattering/Absorption Due to Aerosol Particles in Urban/Suburban Atmosphere of Irbid, Jordan", Jordan Journal of Physics, Vol. 3 No. 2

Hamdi, M. R., Bdour A.; Tarawneh, Z. (2008). Diesel Quality in Jordan: Impacts of Vehicular and Industrial Emissions on Urban Air Quality.

Harber, P., H. Muranko, S. Solis, A. Torossian, and B. Merz. (2003). "Effect of carbon black exposure on respiratory function and symptoms." J Occup Environ Med;45(2):144155.

Horvath, H. (1993). "Atmospheric Light Absorption-A Review." Atmospheric Environment 27A: 293-317.

Horvath, H., "Size Segregated Light Absorption Coefficient of the Atmospheric Aerosol," Atmos. Environ., 29, 875-883 (1995).

Horvath, H. (1997). "Comparison of the light absorption coefficient and carbon measures for remote aerosols: An independent analysis of data from the improve network I and II: Discussion." Atmospheric Environment 13: 2885-2887.

IPCC, Intergovernmental Panel on Climate Change, Contribution of Working Group I to the Second Assessment Report (J.T. Houghton, L. G. Meira Filho, B. A. Callender, N. Harris, A. Kattenberg, and K. Maskell, Eds), Climate Change 1995: The Science of Climate Change, Cambridge Univ. Press, Cambridge, UK, 1996. 
Kassel, R., (2003). Dump Dirty Diesel: The health and Air Quality Benefits of Cleaner Diesel Engines. Diesel Retrofit Workshop, Oct 21.

Kirchstetter, T.W., Novakov, T. And Hobbs, P.V. (2004), Evidence that the spectral dependence of light absorption by aerosols is affected by organic carbon. J. Geophysics. Res. 109(D21):D21208. doi:10.1029/2004JD004999.

Künzli, N., R. Kaiser, S. Medina, M. Studnicka, O. Chanel, P. Filliger, M. Herry,F. Horak, V. Puybonnieux-Texier, P. Quénel, J. Schneider, R. Seethaler, JC.Vergnaud, and H. Sommer, (2000). Public-health impact of outdoor and trafficrelated air pollution: a European assessment. The Lancet. 356(9232), 795-801.

Lewis, K., W.P. Arnott, H. Moosmüller, and E. Wold (2008) "Strong spectral variation of biomass smoke light absorption and single scattering albedo observed with a novel dual-wavelength photoacoustic instrument." Journal of Geophysical research, 113, D16203, doi:10.10292007JD009699.

Lindberg, J. D., Douglass, R. E., and Garvey, D. M. (1993). Carbon and the optical properties of the atmospheric dust. Applied Optics, 32, 6077-6081.

Liousse, C., Cachier, H., and Jennings, S. G. (1993). Optical and thermal measurements of black carbon aerosol content in different environments: Variation of the specific attenuation cross section, sigma ( $\sigma$ ). Atmospheric Environment, 27A, 1203-1211.

Liu, L., and M. H. Smith. "Urban and Rural Aerosol Particle Optical Properties," Atmos. Environ. , 29, 3293-3301 (1995).

Parent ME, J. Siemiatycki, and L. Fritschi, " Workplace Exposures and Oesophagealcancer," Occup Environ Med 2000; 57:325-34

Pope, C.A., Thun, M.J., Namboodira, M., Dockery, D.W., Evans, J.S., Speizer, F.E., Health Jr., C.W., 1995. Particulate air pollution as a predictor of mortality in a prospective study of US adults. American Journal of Respiratory Critical Care Medicine 151, 669-674.

Pope, C.A., Burnett, R.T., Thun, M.J., Calle, E.E., Krewski, D., Ito, K., and Thurston, G.D. (2002): Lung Cancer, Cardiopulmonary Mortality, and Long-term Exposure to Fine Particulate Air Pollution. Journal of American Medical Association, Vol 287, No. 9, 1132-1141.

Puntoni,R., M. Ceppi, V.Gennaro, D. Ugolini, M. Puntoni, G. La Manna, C. Casella, and D. Merlo. (2004). "Occupational exposure to carbon black and risk cancer." Cancer Causes Control; 15(5):511-6

Rosen, H., Hansen, A. D. A., Gundel, and Novakov, T. (1978). Identification of the optically absorbing component in urban aerosols. Applied Optics, 17, 3859-3861.

Sanjay Rajagopalan; Ohio State University (2008, July 29). Exposure To Bad Air Raises Blood Pressure, Study Shows. ScienceDaily. Retrieved October 9, 2008, from http://www.sciencedaily.com /releases/2008/07/.htm

Takano H., Yanagisawa R, Ichinose T, Sadakane K, Yoshino S, Yoshikawa T, ( 2002.( Diesel exhaust particles enhance lung injury related to bacterial endotoxin through expression of proinflammatory cytokines, chemokines, and intercellular adhesion molecule-1. Am J Respir Crit Care Med. 165(9),1329-1335.

Walker, P. L., "Chemistry and physics of carbon". vol. 2, Marcel Dekker Inc., NewYork, USA (1966) 
WHO, Indoor air pollution,

http://www.who.int/indoorair/en/, URL, Dec 8th 2010. 


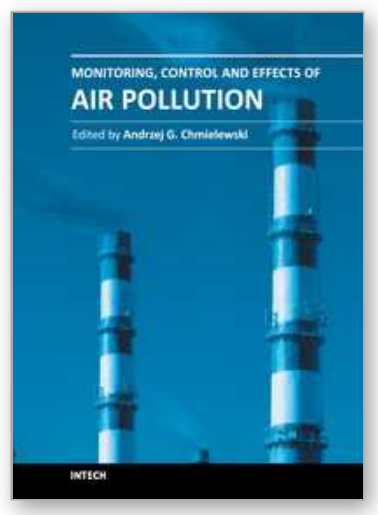

\author{
Monitoring, Control and Effects of Air Pollution \\ Edited by Prof. Andrzej G. Chmielewski
}

ISBN 978-953-307-526-6

Hard cover, 254 pages

Publisher InTech

Published online 23, August, 2011

Published in print edition August, 2011

The book addresses the subjects related to the selected aspects of pollutants emission, monitoring and their effects. The most of recent publications concentrated on the review of the pollutants emissions from industry, especially power sector. In this one emissions from opencast mining and transport are addressed as well. Beside of SOx and NOx emissions, small particles and other pollutants (e.g. VOC, ammonia) have adverse effect on environment and human being. The natural emissions (e.g. from volcanoes) has contribution to the pollutants concentration and atmospheric chemistry governs speciation of pollutants, as in the case of secondary acidification. The methods of ambient air pollution monitoring based on modern instrumentation allow the verification of dispersion models and balancing of mass emissions. The comfort of everyday humanâ $€^{\mathrm{TM}} \mathrm{S}$ activity is influenced by indoor and public transport vehicles interior air contamination, which is effected even by the professional appliances operation. The outdoor pollution leads to cultural heritage objects deterioration, the mechanism are studied and the methods of rehabilitation developed. However to prevent emissions the new technologies are being developed, the new class of these technologies are plasma processes, which are briefly reviewed at the final part of the book.

\title{
How to reference
}

In order to correctly reference this scholarly work, feel free to copy and paste the following:

Khadeejeh M. Hamasha (2011). Photoacoustic Measurements of Black Carbon Light Absorption/Scattering Coefficients and Visibility Degradation in Jordan During 2007/2008, Monitoring, Control and Effects of Air Pollution, Prof. Andrzej G. Chmielewski (Ed.), ISBN: 978-953-307-526-6, InTech, Available from: http://www.intechopen.com/books/monitoring-control-and-effects-of-air-pollution/photoacousticmeasurements-of-black-carbon-light-absorption-scattering-coefficients-and-visibility-d

\section{INTECH}

open science | open minds

\author{
InTech Europe \\ University Campus STeP Ri \\ Slavka Krautzeka 83/A \\ 51000 Rijeka, Croatia \\ Phone: +385 (51) 770447 \\ Fax: +385 (51) 686166 \\ www.intechopen.com
}

\author{
InTech China \\ Unit 405, Office Block, Hotel Equatorial Shanghai \\ No.65, Yan An Road (West), Shanghai, 200040, China \\ 中国上海市延安西路65号上海国际贵都大饭店办公楼 405 单元 \\ Phone: +86-21-62489820 \\ Fax: +86-21-62489821
}


(C) 2011 The Author(s). Licensee IntechOpen. This chapter is distributed under the terms of the Creative Commons Attribution-NonCommercialShareAlike-3.0 License, which permits use, distribution and reproduction for non-commercial purposes, provided the original is properly cited and derivative works building on this content are distributed under the same license. 